\title{
Intracerebral Transplantation of BDNF-overexpressing Human Neural Stem Cells (HB1.F3.BDNF) Promotes Migration, Differentiation and Functional Recovery in a Rodent Model of Huntington's Disease
}

\author{
Hyun Sook Kim ${ }^{1 \dagger}$, Iksoo Jeon ${ }^{2 \dagger}$, Jeong-Eun Noh ${ }^{2}$, Hyunseung Lee ${ }^{3}$, Kwan Soo Hong ${ }^{3}$, Nayeon Lee ${ }^{2}$, \\ Zhong Pei ${ }^{4}$ and Jihwan Song ${ }^{2,5 *}$ \\ ${ }^{1}$ Department of Neurology, CHA Bundang Medical Center, CHA University, Seongnam 13496, ${ }^{2} \mathrm{CHA}$ Stem Cell Institute, \\ Department of Biomedical Science, CHA University, Seongnam $13488,{ }^{3}$ Division of Magnetic Imaging Resonance, \\ Korea Basic Science Institute, Cheongju 28119, Korea, ${ }^{4}$ Department of Neurology, National Key Clinical \\ Department and Key Discipline of Neurology, The First Affiliated Hospital of Sun Yat-sen University, \\ Guangzhou 510080, China, ${ }^{5}$ iPS Bio, Inc., Seongnam 13522, Korea
}

Huntington's disease (HD) is a dominantly inherited neurodegenerative disorder caused by abnormally expanded CAG repeats in the huntingtin gene. The huntingtin gene mutation leads to the progressive degeneration of striatal GABAergic medium spiny neurons (MSN) and reduces the level of brain-derived neurotrophic factor (BDNF) in HD patient's brain. BDNF is an essential neurotrophic factor for the cortico-striatal synaptic activity and the survival of GABAergic neurons. In this study, we transplanted BDNF-overexpressing human neural stem cells (HB1.F3.BDNF) into the contra-lateral side of unilateral quinolinic acid (QA)-lesioned striatum of HD rat model. The results of in vivo transplantation were monitored using various behavioral tests, $4.7 \mathrm{~T}$ animal magnetic resonance imaging (MRI) and immunohistochemical staining. We observed that the QA-lesioned rats receiving HB1.F3.BDNF cells exhibited significant behavioral improvements in the stepping, rotarod and apomorphine-induced rotation tests. Interestingly, contralaterally transplanted cells were migrated to the QA-lesioned striatum and the size of lateral ventricle was reduced. Histological analyses further revealed that the transplanted cells, which had migrated to the QA lesion site, were differentiated into the cells of GABAergic, MSN-type neurons expressing DARPP-32, and neural networks were established between the transplanted cells and the host brain, as revealed by retrograde tracing. Finally, there was a significant reduction of inflammatory response in HB1.F3.BDNF-transplanted HD animal model, compared with vehicle-transplanted group. Taken together, these results suggest that HB1.F3.BDNF can be an effective therapeutic strategy to treat HD patients in the future.

Key words: Huntington's disease (HD), Neural stem cells, Brain-derived neurotrophic factor (BDNF), Magnetic resonance imaging (MRI), Behavioral recovery

\section{INTRODUCTION}

Submitted March 17,2020, Revised April 13,2020,

Accepted April 13,2020

* To whom correspondence should be addressed.

TEL: 82-31-881-7140, FAX: 82-31-881-7249

e-mail: jsong5873@gmail.com

These authors contributed equally to this work.

This is an Open Access article distributed under the terms of the Creative Commons Attribution Non-Commercial License (http://creativecommons.org/licenses/by-nc/4.0) which permits unrestricted non-commercial use, distribution, and reproduction in any medium, provided the original work is properly cited.

Copyright $\odot$ Experimental Neurobiology 2020. www.enjournal.org
Huntington's disease (HD) is an autosomal-dominant neurodegenerative disorder, caused by abnormally expanded CAG repeats in the huntingtin (Htt) gene, located on the short arm of chromosome 4 [1]. Although Htt gene mutation occurs systemically, the most prominent pathology happens to the neuronal cells of cen- 
tral nervous system, and the DNA repair protein-related, somatic instability of $H t t$ gene mutation has been implicated in this striatal selectivity. The mutant huntingtin protein (mHTT) leads to the progressive and selective degeneration of GABAergic medium spiny neurons (MSN) in the caudate nucleus and putamen [2]. Significant motor manifestations including chorea, parkinsonism, dystonia and gait instability as well as cognitive and psychiatric symptoms deteriorate HD patient's daily activity and lead to death in middle age. Apart from some medications (e.g., tetrabenazine) showing limited symptom-relieving effects, there is no cure for $\mathrm{HD}$ and various kinds of stem cells have been investigated in both preclinical and clinical studies. So far, clinical trials of intrastriatal transplantation of fetal neural stem cells, such as fetal tissues from ganglionic eminence or ventral mesencephalon have shown variable outcomes of short-lived clinical benefit with improved motor function, slowed disease progression or no benefit [3-5]. This modest benefit in preliminary clinical studies requires more deliberate therapeutic attempts especially in view of cell types and mechanisms of action.

Brain-derived neurotrophic factor (BDNF), a member of the neurotrophic factor family, is widely distributed in adult mammalian brain [6] and plays an important role in the survival, proliferation and differentiation of neurons [7]. In the striatum, BDNF supports survival of the immature striatal neurons at their origin, promotes maturation of striatal neurons, and facilitates establishment of striatal connections during brain development. BDNF also has its role during adulthood in maintaining proper function of the striatum by promoting survival of MSN and inducing synaptic plasticity [8]. It is also known that impaired synaptic plasticity and increased inflammatory cytokines are related to the BDNF/ TrkB deprivation in various neurological diseases, including AD $[9,10]$. Marked reduction of BDNF and BDNF/TrkB signaling has been reported in many HD animal models and the level of BDNF is also reduced in the postmortem cerebral cortex and striatum of HD patients [11]. Huntingtin protein (HTT) normally participates in vesicular transportation, and the mHTT causes a selective defect of the axonal transport of BDNF from the cerebral cortex to the striatum [12], which has been linked to neuronal cell death in HD. More importantly, mHTT reduces the transcriptional activity of the BDNF promoter, the level of BDNF gene transcription, and subsequent BDNF protein synthesis in the cerebral cortex $[11,13$, 14].

Combinatorial cell and gene therapy approaches using genetically engineered stem cells have been developed to augment the therapeutic effects of stem cells in various intractable diseases. We have previously demonstrated that the immortalized BDNFoverexpressing hNSCs (HB1.F3.BDNF) can be effective in the ischemic stroke model, induced by middle cerebral artery occlusion, as evidenced by a behavioral recovery, neural regeneration and high expression of human BDNF protein in vivo [15]. The migratory capacity and therapeutic potential of HB1.F3 cells, an immortalized, clonal human NSC line, as a gene delivery system was also demonstrated in experimental brain tumor models [16]. As an immortalized human neural stem cell line, HB1.F3.BDNF can differentiate into various neural cell types, depending on the microenvironment where the cells are transplanted (i.e., neurogenic niche), and the presence of other cell types [17, 18]. It has also been demonstrated that immortalized human neural stem cells can survive, migrate and differentiate into neurons displaying GABAergic markers, and functionally integrate into the adult rat brain when injected into the corpus callosum in combination with transient immunosuppression (i.e., administering cyclosporine A) following the ischemic event [19].

In this study, we focused to test the usefulness of HB1.F3.BDNF as a potential source of cell therapy in HD. We have addressed the overall effects of HB1.F3.BDNF, such as whether the transplanted HB1.F3.BDNF can survive, migrate and induce functional improvements in a rodent model of HD. To demonstrate the therapeutic potential of the migrating stem cells in $\mathrm{HD}$, we have chosen the HD rat model induced by QA injection in one side of striatum and transplanted HB1.F3.BDNF in the contralateral side. We have investigated the capacity for restoration of functional deficits using multiple behavioral tests. We have also determined the connection of the transplanted cells to the host brain by using Fluoro-Gold (FG)-mediated axonal tracing. We postulate that contralaterally transplanted HB1.F3.BDNF cells can migrate and differentiate into the MSN-type GABAergic neurons in the QA-lesioned ipsilateral striatal environment and show behavioral benefits in vivo.

\section{MATERIALS AND METHODS}

\section{Quinolinic acid (QA)-lesioned rodent model of Hunting- ton's disease and stem cell transplantation}

QA-lesioned rat model of HD was established using the previously described method [20]. In short, adult male Sprague-Dawley rats (Orient, Seoul, Korea) weighing 250 280 g were used. All rats received a stereotaxic unilateral lesion of the striatum via double injections of quinolinic acid $(0.3 \mathrm{~mol} / \mathrm{l}$ in $1.5 \mu \mathrm{l}$, Fluka) at the following coordinates: $\mathrm{AP}+0.7 \mathrm{~mm}, \mathrm{ML}+2.5 \mathrm{~mm}, \mathrm{DV}-4.5 \mathrm{~mm}$, and $\mathrm{AP}+0.7 \mathrm{~mm}, \mathrm{ML}+2.5 \mathrm{~mm}, \mathrm{DV}-3.5 \mathrm{~mm}$ from the bregma. The HB1.F3.BDNF cells were cultured and maintained as described previously [15]. At 7 days after unilateral QA lesioning, $2 \mu$ of cell suspension (containing a total of 400,000 cells) were injected into the contralateral striatum (AP $+0.2 \mathrm{~mm}, \mathrm{ML}-2.5 \mathrm{~mm}$ and DV -5.5 
$\mathrm{mm}$, from the bregma) over a 4 min period using a $26 \mathrm{G}$ Hamilton syringe in 13 rats. In the vehicle group $(n=8), 2 \mu$ of suspension medium (GMEM) were injected in parallel. All transplanted animals were injected with cyclosporine A (10 mg/kg, Sigma) daily [21].

\section{Behavioral tests}

To minimize the behavioral variation of each animal, all rats were trained three times per day for 3 consecutive days with the same conditions before the injection of QA. On the rotarod test, the average time of endurance on the rotarod cylinder from three trials was recorded in all rats using the acceleration mode of progressively increasing rod speeds from 4 to $40 \mathrm{rpm}$ for $5 \mathrm{~min}$ [22]. In the stepping test [23], the rats were slowly moved sideways placing their forepaws along the $90 \mathrm{~cm}$-width band on the table for $5 \mathrm{sec}$ and the number of forepaw placing was counted. For the apomorphine-induced rotation test, animals were injected with apomorphine $(1.0 \mathrm{mg} / \mathrm{kg}$ in normal saline containing $0.2 \%$ ascorbate, Sigma) and placed in an acrylic box cage individually for a 5 min habituation period before $60 \mathrm{~min}$ test session. The number of complete $360^{\circ}$ ipsilateral turn ("rotation") and the difference between the ipsilateral and the contralateral turns was counted. After the initial test was performed at 6 days after QA injection, apomorphine-induced rotation test was performed biweekly up to 6 weeks following transplantation [24] (Fig. 1A).

\section{Detection of transplanted cells using magnetic resonance imaging (MRI) and Prussian blue staining}

To detect the transplanted cells, we pre-labeled the cells with ferumoxides (Feridex ${ }^{\circledR}$ ) combined with protamine sulfate (Sigma) as a contrasting agent. Feridex ${ }^{\circledR}$-protamine sulfate complex was prepared at a concentration of $2 \mu \mathrm{g} / \mathrm{ml}$ in the culture medium without serum, and it was subsequently incubated for $30 \mathrm{~min}$ at room temperature. An equal volume of culture medium and the
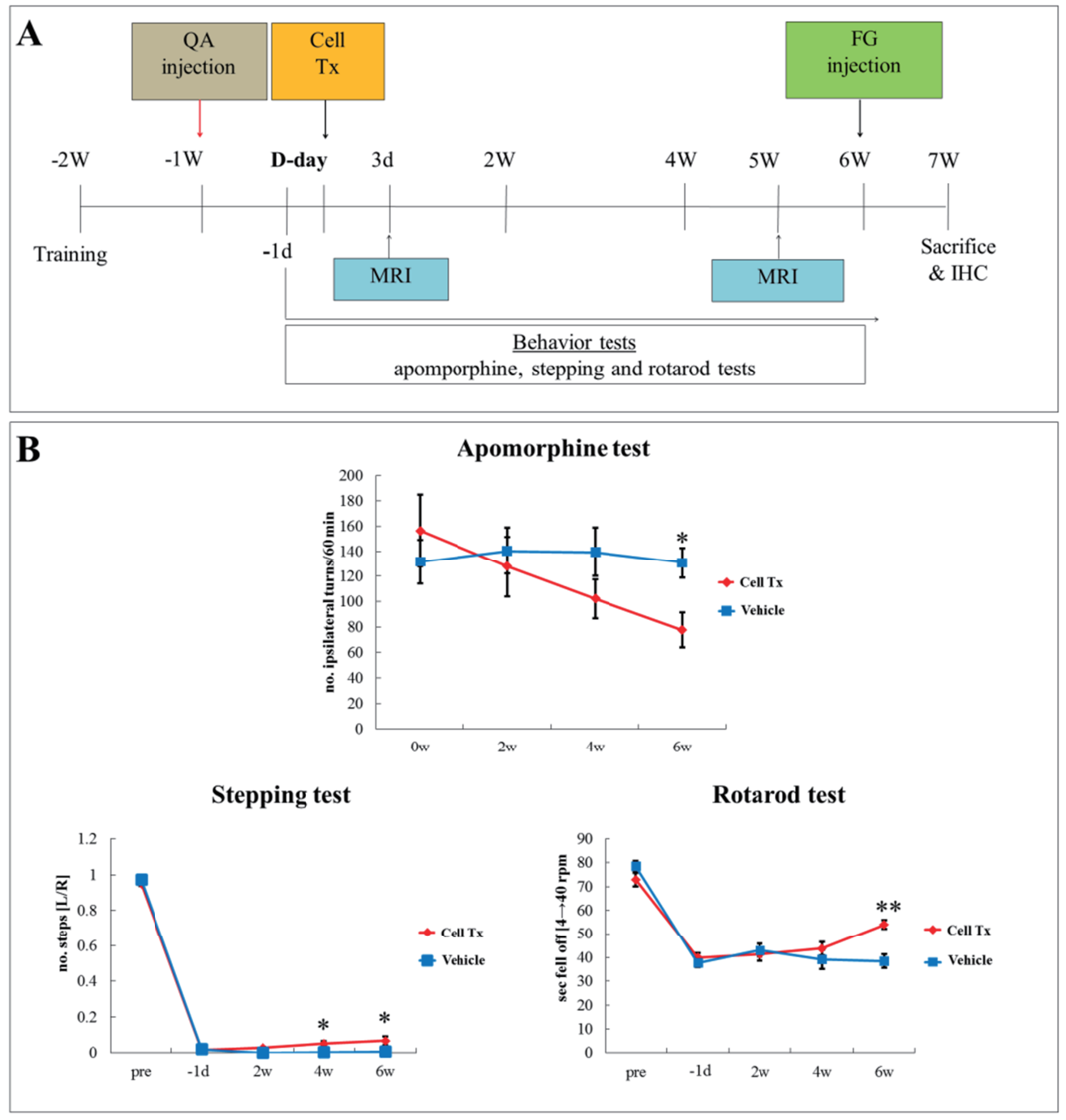

Fig. 1. Behavioral tests in the rat model of HD after contralateral transplantation of HB1.F3.BDNF cells. (A) Experimental scheme showing the schedules for behavioral training and three consecutive tests as well as toxin-induced HD modeling and cell transplantation. (B) In the apomorphineinduced rotation, stepping and rotarod tests, behavioral performance of HB1.F3.BDNF transplanted rats $(\mathrm{n}=13)$ was improved at 6 weeks after transplantation, compared with vehicle-injected rats $(n=8)$. Data are presented as mean \pm SEM. ${ }^{*}$ denotes $p<0.5$ and ${ }^{* *}$ denotes $\mathrm{p}<0.001$ in two-way ANOVA. 
Feridex ${ }^{\circledR}$-protamine sulfate complex was added to HB1.F3.BDNF cells and incubated overnight at $37^{\circ} \mathrm{C}$. Afterwards, the medium was removed, and the cells were washed twice with PBS. To detect whether Feridex ${ }^{\circledR}$-labeled cells can migrate, $2^{*}$ imaging using a 7.0 T MRI (BioSpec 70/20, Bruker, Germany) was employed to track the location of labeled cells on the 3rd and 35th day (i.e., 5th week) following transplantation. The Feridex ${ }^{\circledR}$-labeled cells were also identified using Prussian blue staining histologically $[15,25]$.

\section{Immunohistochemical analysis and neuronal tracing}

To detect the engraftment of transplanted HB1.F3.BDNF cells in the host brain, $1 \mu \mathrm{l}$ of a retrograde tracer, Fluoro-Gold (2\% solution dissolved in sterile saline, Fluorochrome, USA) was stereotaxically injected into the globus pallidus of the QA-lesioned hemisphere (AP: $-1.0 \mathrm{~mm}$, ML: $+2.5 \mathrm{~mm}, \mathrm{DV}:-6.0 \mathrm{~mm}$ ) at 6 weeks after transplantation. We sacrificed the rats at 7 weeks posttransplantation, and performed histological procedures on the brain using 4\% paraformaldehyde, 30\% sucrose and OCT compound, sequentially. Immunostaining was performed on the freefloating $40 \mu \mathrm{m}$-thick sectioned brain tissues using the following primary antibodies, in combination with appropriate Alexa Fluorconjugated secondary antibodies: human-specific nuclei $(\mathrm{hNu})$ (1:100, Chemicon), DARPP-32 (1:100, Cell Signaling), glial fibrillary acidic protein (GFAP) (1:500, BD Bioscience), and ED1 (1:200,
Bio-Rad). Afterwards, the sections were counterstained with the nuclear marker, 4', 6-diamidine-29-phenylindole dihydrochloride (DAPI). To detect the Feridex ${ }^{\circledR}$-labeled cells histologically, Prussian blue staining was performed on the tissue sections fixed with methanol for $30 \mathrm{~min}$ at room temperature, treated with a mixture of $4 \%$ potassium ferrocyanide and $4 \% \mathrm{HCl}$ solution, followed by boiling. Immunohistochemically stained brain sections were analyzed under a confocal microscopy (LSM510, Carl Zeiss, Germany). Brain sections with Prussian blue staining were examined under a light microscope (Eclipse E600, Nikon, Japan).

\section{Statistical analysis}

Statistical analyses were performed using SigmaPlot 12.0 (Systat Software, Inc). All values were presented as the means \pm S.E.M (standard error of mean). Statistical significance on the difference between cell-transplanted and vehicle groups for behavioral scores was analyzed by two-way analysis of variance (ANOVA). Statistical significance on the difference between cell-transplanted and vehicle groups for tissue analysis was analyzed by t-test. The probability value $<0.05$ was considered statistically significant.

\section{RESULTS AND DISCUSSION}

To test if there was any behavioral improvement following a con-
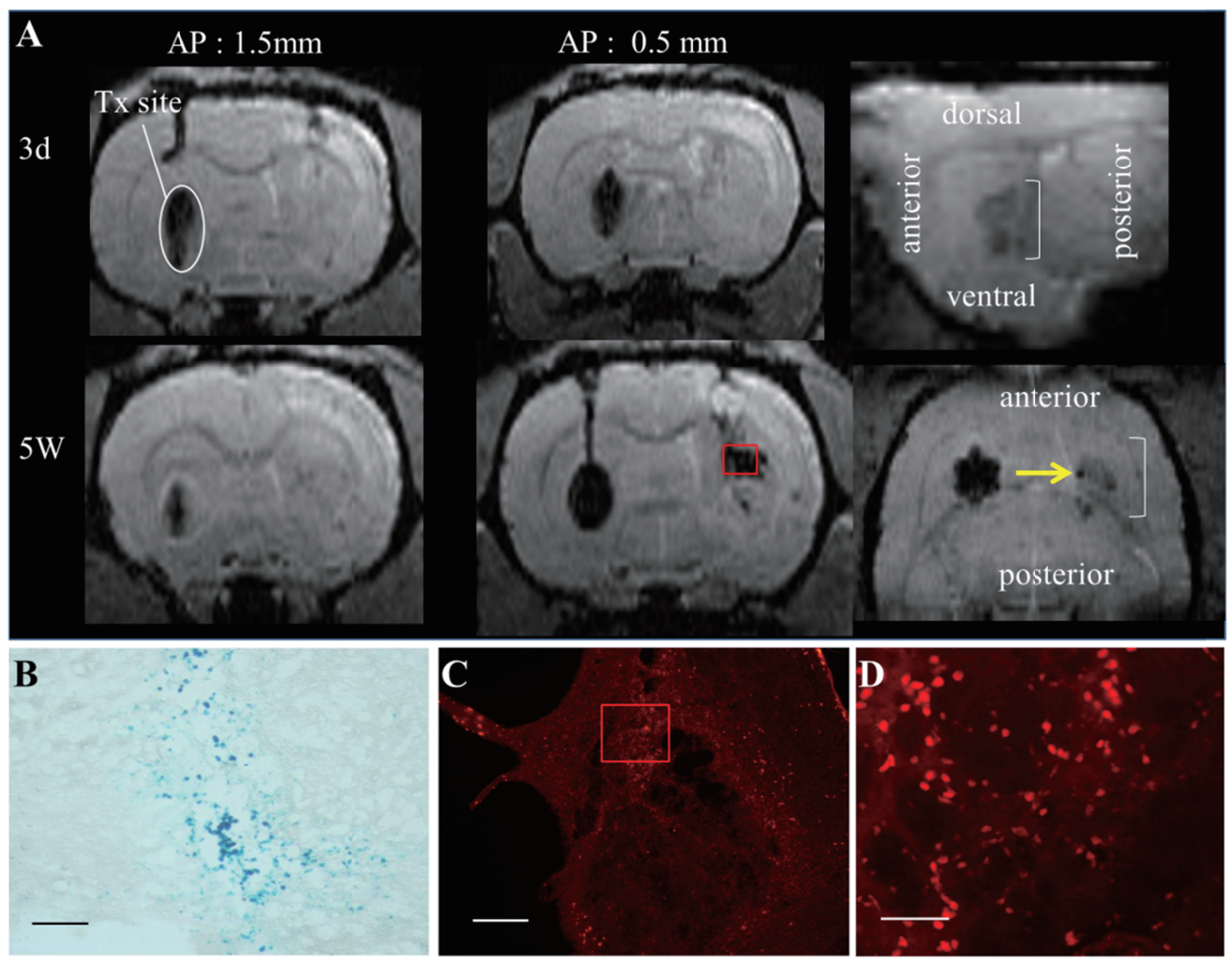

Fig. 2. Localization of Feridex ${ }^{\circledR}$ labeled HB1.F3.BDNF cells on the brain MRI scan. (A) At 3 days after transplantation, Feridex ${ }^{\circledR}$ signal was well-visualized at the injection site (left side on the MR image, corresponding to the right side of the anterior striatum), contralateral to the QA-lesion side in the coronal view and the sagittal view (upper panel). At 5 weeks after transplantation, Feri$\operatorname{dex}^{\circledR}$ signal was identified on the contralateral side of the injection in coronal and axial views (lower panel). (B) Detection of migrated Feridex ${ }^{\circledR}$-labeled HB1.F3.BDNF cells at the QA-lesioned site by Prussian blue staining. (C, D) Immunohistochemical staining using human nuclei $(\mathrm{hNu})$ antibody showing the presence of transplanted human cells. Scale bar: $B, C=100 \mu \mathrm{m}, \mathrm{D}=20 \mu \mathrm{m}$. 
tralateral transplantation of HB1.F3.BDNF cells into the unilateral QA-lesioned rat model, we designed and planned the experimental schedule for toxin-induced HD modeling, cell transplantation, behavioral tests, MRI, Fluoro-Gold injection, and immunohistochemistry, as shown in Fig. 1A. Functional effects of contralaterally transplanted HB1.F3.BDNF cells were evaluated using three behavioral tests (i.e., stepping, rotarod and apomorphine-induced rotation tests) up to 6 weeks following transplantation. We found that in the apomorphine-induced rotation test, no significant difference between cell-transplanted and vehicle groups was observed until 4 weeks following transplantation. However, celltransplanted group started to show a significant improvement compared to the vehicle group at 6 weeks (Fig. 1 B, p value $<0.05$ ). In the stepping test, cell-transplanted group exhibited a significantly improved performance compared to the vehicle group starting from 4 weeks after transplantation (Fig. 1B, p value $<0.05$ ). On the rotarod test, a significant behavioral recovery was observed from 6 weeks after transplantation, compared to the vehicle group (Fig. 1B, p value $<0.05$ ). These results indicate that contralaterally transplanted HB1.F3.BDNF cells led to a significant behavioral improvement as early as 4 weeks after transplantation.

To assess the migrating capacity of HB1.F3.BDNF cells in vivo, the cells were pre-labeled with ferumoxides (Feridex ${ }^{\circledR}$ )-protamine sulfate complex in vitro and were transplanted into the contralateral striatum of the QA-lesioned hemisphere. We performed brain MRI scan on the transplanted animals $(n=3)$ at day 3 and 5 weeks after transplantation to detect the Feridex ${ }^{\circledR}$-labeled cells. Due to the contrast effect, a collection of Feridex ${ }^{\circledR}$-positive cells appeared as a black area on the MRI scan. We found that at three days after transplantation, the transplanted cells were detected in the QAlesioned site as a dark area on the MRI scan in the sagittal view (Fig. $2 \mathrm{~A}$, upper panel). At five weeks after transplantation, we found that a substantial number of contralaterally transplanted cells migrated to the QA-lesioned striatum, close to the AP $1.5 \mathrm{~mm}$ to $-0.5 \mathrm{~mm}$ from the bregma (Fig. 2A, lower panel). These results strongly suggest an in vivo migration of transplanted HB1.F3.BDNF cells from the injection site to the QA-lesion site. The graft survival and migration were also visualized and confirmed by Prussian blue staining (Fig. 2B), as well as immunostaining with hNu antibody using confocal analysis (Fig. 2C). These findings strongly support that HB1.F3.BDNF cells can survive at least up to 7 weeks after transplantation and they can migrate to the damaged striatum.

To determine whether HB1.F3.BDNF cells can make neural connections with host cells after transplantation, a retrograde tracer FG (Fluorochrome) [26] was injected into the globus pallidus of the QA-lesioned hemisphere at 6 weeks after transplantation and the animals were sacrificed one week later. The ability of the trans- planted cells to establish a neural network with the host cells can be partly determined by the presence of retrograde transportation to the transplanted cells. Interestingly, we observed that the contralaterally transplanted cells migrated to the ipsilateral hemisphere and the migrated cells were colocalized with the FG signals (Fig. $3 \mathrm{~A}$ and $3 \mathrm{~B}$ ). Moreover, we also observed that a high proportion of migrated hNu-positive, transplanted HB1.F3.BDNF cells were differentiated into DARPP32-positive medium spiny neurons (MSN) (Fig. 3C), the key neuronal population known to be selectively degenerated in HD. These findings suggest that the transplanted cells differentiated to DARPP32-positive MSN and formed functional connections in the HD animal model.

Extensive astrocytosis and microgliosis are typically observed in the brains of HD patients [27]. In addition, microglial accumulation in the corresponding region of neuronal loss can be observed at all stages of HD [28]. Microglia are reported to produce excessive amount of QA under pathological condition [29], which implies an active participation of microglia in the neurodegenerative process. Therefore, we utilized the QA-lesioned HD model [30] to mimic the pathological events that occur in the brain of HD patients. To
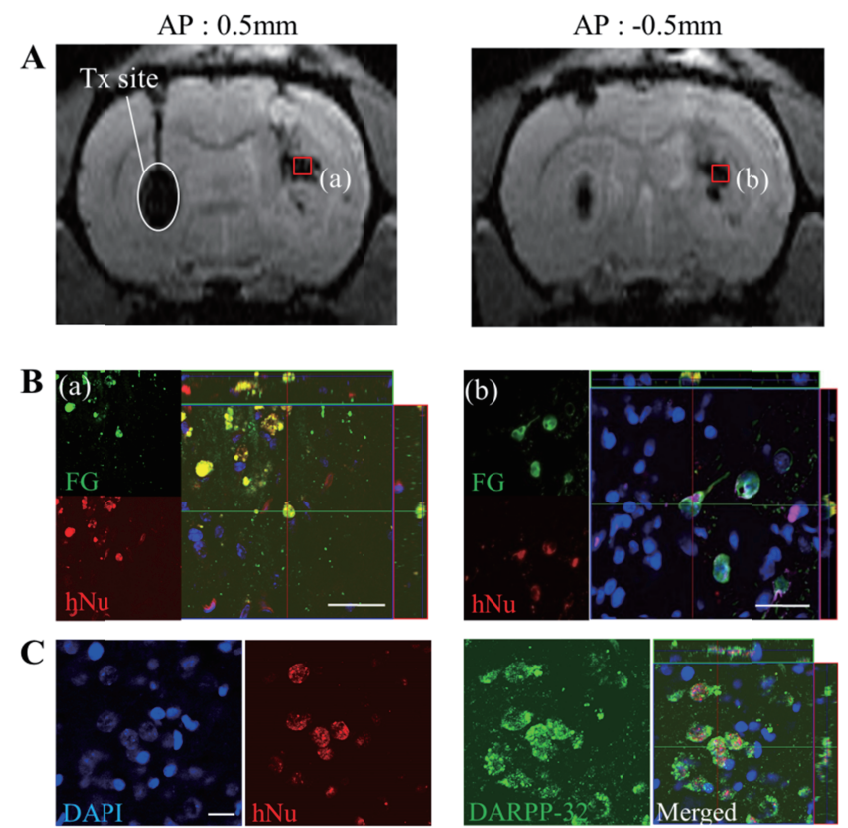

Fig. 3. Neuroanatomical tracing of HB1.F3.BDNF-derived DARPP32-positive cells in vivo using Fluoro-Gold (FG) retrograde labeling. (A) The transplantation site of HB1.F3.BDNF cells is indicated on the brain MRI scan (white oval), and the location of Feridex ${ }^{\circledR}$-labeled migrated cells is visualized at two sites (red boxes) in the QA-lesioned striatum: (a) AP: 0.5 mm, (b) AP: $-0.5 \mathrm{~mm}$. (B) Co-localization of migrated human cells with FG-positive signals at sites (a) and (b) in the QA-lesioned striatum. (C) Detection of DARPP-32-expressing hNu-positive cells at site (b) of the QA-lesioned striatum. Scale bar $=20 \mu \mathrm{m}$. 


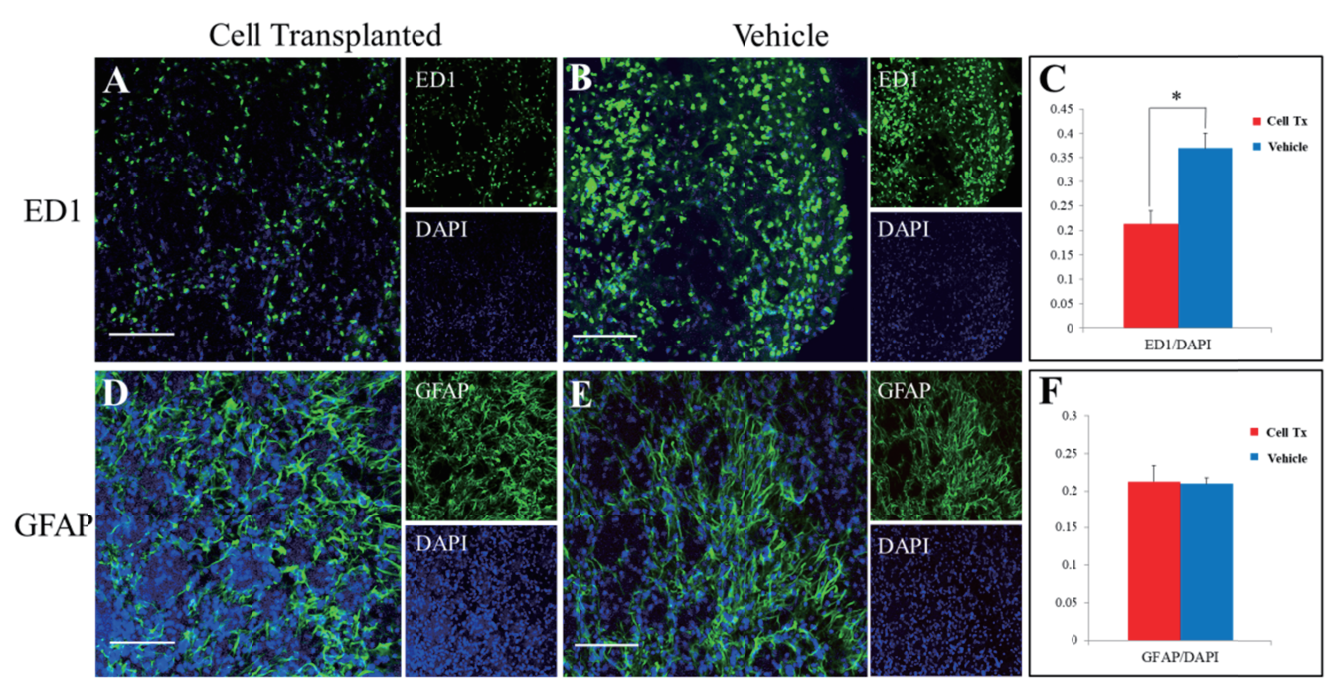

Fig. 4. Changes of the inflammatory responses in QA-lesioned rat brain after transplantation of HB1.F3.BDNF. (A, B) Decrease of ED1-positive microglial cells following transplantation. (C) Significant difference was observed between cell-transplanted $(n=13)$ and vehicle $(n=8)$ groups. (D, E) Expression of GFAP-positive astroglial cells following transplantation. (F) No significant difference was observed between cell-transplanted and vehicle groups. Data are presented as mean \pm SEM. ${ }^{*} \mathrm{p}<0.05$. Scale bar $=100 \mu \mathrm{m}$. investigate whether astrocytosis and microgliosis occur in the QAlesioned brains, we performed immunohistochemistry using antibodies against ED1 (a microglial marker) and GFAP (an astrocyte marker). We found that compared to the vehicle group, the number of ED1-positive cells was significantly reduced in the HB1.F3.BDNF transplanted group (Fig. 4A 4C) $(\mathrm{p}<0.05)$. Reduced microglial activity implies that the transplanted HB1.F3.BDNF cells can decrease neurotoxic inflammation. However, no significant difference in the expression of GFAP was observed between HB1.F3.BDNF transplanted group and vehicle group (Fig. 4D 4F), suggesting hypertrophic astrocytes are present in both groups. It has been proposed recently that proBDNF-positive/GABA-negative hypertrophic astrocytes are 'active' astrocytes and GABA-positive hypertrophic astrocytes are 'reactive' astrocytes [31]. Therefore, it will be necessary to delineate the role of HB1.F3.BDNF cells whether they can switch the hypertrophic astrocytes from 'reactive' to active' astrocytes in our future study.

Stem cell therapy has received a special attention from those who have unmet medical needs and is considered as a potential treatment for diverse neurological diseases, including HD. BDNFmediated loss-of-function has been implicated in the pathophysiology of MSN degeneration in the striatum of HD patients [32, 33] because BDNF is a lead neurotrophic factor to promote the survival and maturation of MSN in the striatum [34, 35]. Among various preclinical studies using fetal neural stem/progenitor cells as well as iPSCs, genetically modified stem cells overexpressing BDNF has shown their best efficacies. Intrastriatally transplanted human mesenchymal stem/stromal cells (MSC) and genetically modified MSC overexpressing BDNF showed their efficacy on disease progression, anxiety and neurogenesis to certain degrees [36]. Embryonic stem cell-derived BDNF-overexpressing neural progenitors also showed efficacy on recovery promotion through enhanced striatal differentiation [37]. In the present study, we have shown that BDNF-overexpressing neural progenitor cells can be another potential source of cell-and-BDNF combination therapy, which can be developed for clinical applications in the future.

\section{ACKNOWLEDGEMENTS}

This work was supported by grants from the National Research Foundation of Korea (NRF-2017M3A9B4061407 and NRF2018M3C7A1056894) and the Korea Health Industry Development Institute (KHIDI), funded by the Ministry of Health and Welfare (HI16C1559), Republic of Korea, and an internal funding from iPS Bio, Inc. We are grateful for Prof. Seung U. Kim and Dr. Hong Jun Lee for kindly providing us with the HB1.F3.BDNF cells for this study.

\section{AUTHOR CONTRIBUTIONS}

H.S.K., I.J. and J.S. were responsible for the study concept and design. I.J., H.L., K.S.H., N.L. and Z.P. were responsible for data acquisition. H.S.K., I.J., H.A, C.J.L. and J.S. performed data analysis and manuscript writing. J.S. finalized the manuscript. H.S.K. and I.J. contributed equally.

\section{REFERENCES}

1. MacDonald ME, Ambrose CM, Duyao MP, Myers RH, Lin C, Srinidhi L, Barnes G, Taylor SA, James M, Groot N, MacFarlane H, Jenkins B, Anderson MA, Wexler NS, Gusella JF, Bates GP, Baxendale S, Hummerich H, Kirby S, North M, 
Youngman S, Mott R, Zehetner G, Sedlacek Z, Poustka A, Frischauf A, Lehrach H, Buckler AJ, Church D, DoucetteStamm L, O'Donovan MC, Riba-Ramirez L, Shah M, Stanton VP, Strobel SA, Draths KM, Wales JL, Dervan P, Housman DE, Altherr M, Shiang R, Thompson L, Fielder T, Wasmuth JJ, Tagle D, Valdes J, Elmer L, Allard M, Castilla L, Swaroop M, Blanchard K, Collins FS, Snell R, Holloway T, Gillespie K, Datson N, Shaw D, Harper PS (1993) A novel gene containing a trinucleotide repeat that is expanded and unstable on Huntington's disease chromosomes. Cell 72:971-983.

2. Kelly CM, Dunnett SB, Rosser AE (2009) Medium spiny neurons for transplantation in Huntington's disease. Biochem Soc Trans 37(Pt 1):323-328.

3. Bachoud-Lévi AC, Rémy P, Nguyen JP, Brugières P, Lefaucheur JP, Bourdet C, Baudic S, Gaura V, Maison P, Haddad B, Boissé MF, Grandmougin T, Jény R, Bartolomeo P, Dalla Barba G, Degos JD, Lisovoski F, Ergis AM, Pailhous E, Cesaro P, Hantraye P, Peschanski M (2000) Motor and cognitive improvements in patients with Huntington's disease after neural transplantation. Lancet 356:1975-1979.

4. Rosser AE, Barker RA, Harrower T, Watts C, Farrington M, Ho AK, Burnstein RM, Menon DK, Gillard JH, Pickard J, Dunnett SB; NEST-UK (2002) Unilateral transplantation of human primary fetal tissue in four patients with Huntington's disease: NEST-UK safety report ISRCTN no 36485475. J Neurol Neurosurg Psychiatry. 73:678-685.

5. Gallina P, Paganini M, Lombardini L, Mascalchi M, Porfirio B, Gadda D, Marini M, Pinzani P, Salvianti F, Crescioli C, Bucciantini S, Mechi C, Sarchielli E, Romoli AM, Bertini E, Urbani S, Bartolozzi B, De Cristofaro MT, Piacentini S, Saccardi R, Pupi A, Vannelli GB, Di Lorenzo N (2010) Human striatal neuroblasts develop and build a striatal-like structure into the brain of Huntington's disease patients after transplantation. Exp Neurol 222:30-41.

6. Altar CA, Cai N, Bliven T, Juhasz M, Conner JM, Acheson AL, Lindsay RM, Wiegand SJ (1997) Anterograde transport of brain-derived neurotrophic factor and its role in the brain. Nature 389:856-860.

7. Davies AM (1994) The role of neurotrophins in the developing nervous system. J Neurobiol 25:1334-1348.

8. Baydyuk M, Xu B (2014) BDNF signaling and survival of striatal neurons. Front Cell Neurosci 8:254.

9. Lima Giacobbo B, Doorduin J, Klein HC, Dierckx RAJO, Bromberg E, de Vries EFJ (2019) Brain-derived neurotrophic factor in brain disorders: focus on neuroinflammation. Mol Neurobiol 56:3295-3312.

10. Wang ZH, Xiang J, Liu X, Yu SP, Manfredsson FP, Sandoval
IM, Wu S, Wang JZ, Ye K (2019) Deficiency in BDNF/TrkB neurotrophic activity stimulates $\delta$-secretase by upregulating $\mathrm{C} / \mathrm{EBP} \beta$ in Alzheimer's disease. Cell Rep 28:655-669.e5.

11. Zuccato C, Marullo M, Conforti P, MacDonald ME, Tartari M, Cattaneo E (2008) Systematic assessment of BDNF and its receptor levels in human cortices affected by Huntington's disease. Brain Pathol 18:225-238.

12. Gauthier LR, Charrin BC, Borrell-Pagès M, Dompierre JP, Rangone H, Cordelières FP, De Mey J, MacDonald ME, Lessmann V, Humbert S, Saudou F (2004) Huntingtin controls neurotrophic support and survival of neurons by enhancing BDNF vesicular transport along microtubules. Cell 118:127138.

13. Zuccato C, Ciammola A, Rigamonti D, Leavitt BR, Goffredo D, Conti L, MacDonald ME, Friedlander RM, Silani V, Hayden MR, Timmusk T, Sipione S, Cattaneo E (2001) Loss of huntingtin-mediated BDNF gene transcription in Huntington's disease. Science 293:493-498.

14. Zuccato C, Liber D, Ramos C, Tarditi A, Rigamonti D, Tartari M, Valenza M, Cattaneo E (2005) Progressive loss of BDNF in a mouse model of Huntington's disease and rescue by BDNF delivery. Pharmacol Res 52:133-139.

15. Chang DJ, Lee N, Choi C, Jeon I, Oh SH, Shin DA, Hwang TS, Lee HJ, Kim SU, Moon H, Hong KS, Kang KS, Song J (2013) Therapeutic effect of BDNF-overexpressing human neural stem cells (HB1.F3.BDNF) in a rodent model of middle cerebral artery occlusion. Cell Transplant 22:1441-1452.

16. Kim SK, Kim SU, Park IH, Bang JH, Aboody KS, Wang KC, Cho BK, Kim M, Menon LG, Black PM, Carroll RS (2006) Human neural stem cells target experimental intracranial medulloblastoma and deliver a therapeutic gene leading to tumor regression. Clin Cancer Res 12:5550-5556.

17. Buzanska L, Zychowicz M, Kinsner-Ovaskainen A (2018) Bioengineering of the human neural stem cell niche: a regulatory environment for cell fate and potential target for neurotoxicity. Results Probl Cell Differ 66:207-230.

18. Markiewicz I, Sypecka J, Domanska-Janik K, Wyszomirski T, Lukomska B (2011) Cellular environment directs differentiation of human umbilical cord blood-derived neural stem cells in vitro. J Histochem Cytochem 59:289-301.

19. Rota Nodari L, Ferrari D, Giani F, Bossi M, RodriguezMenendez V, Tredici G, Delia D, Vescovi AL, De Filippis L (2010) Long-term survival of human neural stem cells in the ischemic rat brain upon transient immunosuppression. PLoS One 5:e14035.

20. Jeon I, Lee N, Li JY, Park IH, Park KS, Moon J, Shim SH, Choi C, Chang DJ, Kwon J, Oh SH, Shin DA, Kim HS, Do JT, Lee 
DR, Kim M, Kang KS, Daley GQ, Brundin P, Song J (2012) Neuronal properties, in vivo effects, and pathology of a Huntington's disease patient-derived induced pluripotent stem cells. Stem Cells 30:2054-2062.

21. Osman MM, Lulic D, Glover L, Stahl CE, Lau T, van Loveren H, Borlongan CV (2011) Cyclosporine-A as a neuroprotective agent against stroke: its translation from laboratory research to clinical application. Neuropeptides 45:359-368.

22. Hanna J, Wernig M, Markoulaki S, Sun CW, Meissner A, Cassady JP, Beard C, Brambrink T, Wu LC, Townes TM, Jaenisch R (2007) Treatment of sickle cell anemia mouse model with iPS cells generated from autologous skin. Science 318:19201923.

23. Olsson M, Nikkhah G, Bentlage C, Björklund A (1995) Forelimb akinesia in the rat Parkinson model: differential effects of dopamine agonists and nigral transplants as assessed by a new stepping test. J Neurosci 15(5 Pt 2):3863-3875.

24. Nakao N, Itakura T (2000) Fetal tissue transplants in animal models of Huntington's disease: the effects on damaged neuronal circuitry and behavioral deficits. Prog Neurobiol 61:313-338.

25. Kim D, Chun BG, Kim YK, Lee YH, Park CS, Jeon I, Cheong C, Hwang TS, Chung H, Gwag BJ, Hong KS, Song J (2007) In vivo tracking of human mesenchymal stem cells in experimental stroke. Cell Transplant 16:1007-1012.

26. Conte-Perales L, Barroso-Chinea P, Rico AJ, Gómez-Bautista V, López IP, Roda E, Wouterlood FG, Lanciego JL (2010) Neuroanatomical tracing combined with in situ hybridization: analysis of gene expression patterns within brain circuits of interest. J Neurosci Methods 194:28-33.

27. Singhrao SK, Neal JW, Morgan BP, Gasque P (1999) Increased complement biosynthesis by microglia and complement activation on neurons in Huntington's disease. Exp Neurol 159:362-376.

28. Sapp E, Kegel KB, Aronin N, Hashikawa T, Uchiyama Y, Tohyama K, Bhide PG, Vonsattel JP, DiFiglia M (2001) Early and progressive accumulation of reactive microglia in the Huntington disease brain. J Neuropathol Exp Neurol 60:161-172.

29. Moresco RM, Lavazza T, Belloli S, Lecchi M, Pezzola A, Todde S, Matarrese M, Carpinelli A, Turolla E, Zimarino V, Popoli P,
Malgaroli A, Fazio F (2008) Quinolinic acid induced neurodegeneration in the striatum: a combined in vivo and in vitro analysis of receptor changes and microglia activation. Eur J Nucl Med Mol Imaging 35:704-715.

30. Chen Y, Carter RL, Cho IK, Chan AW (2014) Cell-based therapies for Huntington's disease. Drug Discov Today 19:980984.

31. Chun H, An H, Lim J, Woo J, Lee J, Ryu H, Lee CJ (2018) Astrocytic proBDNF and tonic GABA distinguish active versus reactive astrocytes in hippocampus. Exp Neurobiol 27:155170 .

32. Ferrer I, Goutan E, Marín C, Rey MJ, Ribalta T (2000) Brainderived neurotrophic factor in Huntington disease. Brain Res 866:257-261.

33. Strand AD, Baquet ZC, Aragaki AK, Holmans P, Yang L, Cleren C, Beal MF, Jones L, Kooperberg C, Olson JM, Jones KR (2007) Expression profiling of Huntington's disease models suggests that brain-derived neurotrophic factor depletion plays a major role in striatal degeneration. J Neurosci 27:11758-11768.

34. Mizuno K, Carnahan J, Nawa H (1994) Brain-derived neurotrophic factor promotes differentiation of striatal GABAergic neurons. Dev Biol 165:243-256.

35. Ivkovic S, Ehrlich ME (1999) Expression of the striatal DARPP-32/ARPP-21 phenotype in GABAergic neurons requires neurotrophins in vivo and in vitro. J Neurosci 19:54095419.

36. Pollock K, Dahlenburg H, Nelson H, Fink KD, Cary W, Hendrix K, Annett G, Torrest A, Deng P, Gutierrez J, Nacey C, Pepper K, Kalomoiris S, D Anderson J, McGee J, Gruenloh W, Fury B, Bauer G, Duffy A, Tempkin T, Wheelock V, Nolta JA (2016) Human mesenchymal stem cells genetically engineered to overexpress brain-derived neurotrophic factor improve outcomes in Huntington's disease mouse models. Mol Ther 24:965-977.

37. Zimmermann T, Remmers F, Lutz B, Leschik J (2016) ESCderived BDNF-overexpressing neural progenitors differentially promote recovery in Huntington's disease models by enhanced striatal differentiation. Stem Cell Reports 7:693706. 